\title{
DRUMMOND E A "INICIAÇÃO LITERÁRIA"
}

\author{
George Luiz França \\ CA / UFSC
}

RESUMO: Drummond, no poema "Iniciação literária" de seu Boitempo II, encampa a imagem da navegação e rememora a leitura como desejo da partida, movimento que transparece em várias evocações da biblioteca de infância. Da partida, caberia perguntar qual o destino de seu trabalho na "iniciação literária" hoje. As políticas de ensino de literatura, em especial no Ensino Médio, são pensadas ainda e sempre a partir de diretrizes historiográficas que preconizam a história da literatura nacional à experiência do texto literário. Pensando Drummond como poeta lido como chave não apenas do Modernismo, mas também do século XX, poeta-estátua de Copacabana, poeta-nacional, poeta-funcionário público, a pergunta que cabe é: quem é o Drummond-escola (aliás, nome também de muitos colégios)? Que Drummond os livros didáticos, herdeiros das antologias, arquivam para o repertório de um estudante de Ensino Médio? Que leitura é feita dessa antologia de Drummond, dado que, além de selecionar, os livros hoje escolhem modos de ler, leituras válidas e validadas, em que pulsa a morte, como em todo arquivo? Este texto aborda a seleção de leituras do poeta realizada por obras selecionadas pelo Programa Nacional do Livro e do Material Didático (PNLD, 2017) para uso nos próximos três anos nas escolas públicas brasileiras, problematizando a cristalização da imagem do "poeta nacional".

PALAVRAS-CHAVE: Carlos Drummond de Andrade; Ensino de Literatura; Livro didático.

\section{DRUMMOND AND THE "LITERARY NOVITIATE"}

ABSTRACT: Drummond, in a poem called "Iniciação literária", from his book Boitempo II, uses the image of the ship and remembers his readings as a desire of going away. This movement appears many times in his works, especially when he recalls his childhood's library. But our question here is: what is Drummond's works destiny in Brazilian schools nowadays? Literature teaching policies, especially for high school, are based in historiographic guidelines that advocates the history of national literature instead of reading literature itself. Drummond is one of the most important poets of Brazilian modern literature, has a statue in Copacabana, was a public agent and is a representative icon of the nation; but which Drummond do we know in school? Who is Drummond in high school textbooks, and does he determine the students' repertoire? In which way his selected works are read, since textbooks also choose ways to read and validate readings? This essay aims to analyze the approach to Drummond's writings in high school textbooks selected by the Programa Nacional do Livro e do Material Didático (PNLD) for the next three years, discussing the survival of the image of a national poet.

KEYWORDS: Carlos Drummond de Andrade; Literary Education; Brazilian Textbooks.

George Luiz França é doutor pelo Programa de Pós-Graduação em Literatura da Universidade Federal de Santa Catarina e professor de Língua Portuguesa e Literatura Brasileira do Colégio de Aplicação da Universidade Federal de Santa Catarina. 


\title{
DRUMMOND E A “INICIAÇÃO LITERÁRIA”
}

\author{
George França
}

\author{
INICIAÇÃO LITERÁRIA \\ Leituras! Leituras! \\ Como quem diz: Navios... Sair pelo mundo \\ voando na capa vermelha de Júlio Verne. \\ Mas por que me deram para livro escolar \\ a Cultura dos campos de Assis Brasil? \\ O mundo é só fosfatos - lotes de 25 hectares \\ - soja - fumo - alfafa - batata-doce - mandioca - \\ pastos de cria - pastos de engorda. \\ Se algum dia eu for rei, baixarei um decreto \\ condenando este Assis a ler sua obra. ${ }^{1}$
}

Assim é o poema em que, no Boitempo II - Menino antigo, Drummond faz uma posta em jogo da Iniciação literária. Em que pese o pêndulo percebido e lido em sua poesia, entre o menino itabirano e a memorialística que perpassa em especial sua última poesia - aquilo que Silviano Santiago chamou de viés proustiano do poeta, ou ainda, da ambiguidade entre a ruptura, o desejo de sair do lugar, e o apego às tradições do clã familiar² - o poema põe em jogo a

${ }^{1}$ ANDRADE, Carlos Drummond de. Iniciação literária. In: Nova reunião: 23 livros de poesia. São Paulo: Companhia das Letras, 2015, p. 603.

2 A formulação sobre Drummond feita por Silviano encontra-se no livro que leva o nome do poeta, datado de 1976, no qual aparecem como linhas de força o mito do "começo" - ligado ao desejo de começar ele mesmo uma nova sociedade e negar os valores do clã, figurada em sua admiração por Robinson Crusoé - e o mito da origem - no qual esse mesmo começo dado em ruptura é negado e se reafirma o peso e o valor da tradição e do passado. Anos depois, no texto Entre Marx e Proust, publicado no suplemento Folhetim, da Folha de São Paulo, essa formulação antinômica retornaria, nomeando-se, já nos estertores da ditadura, a figura de Marx no polo revolucionário, em detrimento de Robinson Crusoé (personagem tão frequente em Drummond), e em Vale quanto pesa (1982) serviria para pensar nossa elite pensante de maneira mais ampla, e não apenas o caso drummondiano. A propósito deste poema, na convivência entre o desejo de sair pelo mundo em navios e tornar-se rei e assinar decretos. (Cf. SANTIAGO, Silviano. Carlos Drummond de Andrade. Petrópolis: Vozes, 1976.) João Luiz Lafetá, por sua vez, perceberá que “[...] essa ambiguidade ideológica cumpre uma função de espelho - espelho no qual o intelectual-brasileiro-classe-dominante se vê refletido, busca se conhecer melhor em seus acertos e desacertos. Para parafrasear Antonio Candido diríamos: instrumento de autodescoberta e auto-interpretação." LAFETÁ, João Luiz. A dimensão da noite e outros ensaios. São Paulo: Duas Cidades; Ed. 34, 2004, p. 235. 
formação do menino como sujeito leitor. De certa maneira, ao descrever sua Iniciação literária, do que menos fala o eu lírico é de literatura: ressalta em sua primeira estrofe o caráter fantasioso do voo ou da navegação (o topos da leitura como viagem) facultada pelo fantástico mundo de Júlio Verne, enfatizando o mundo da leitura como possibilidade de saída do lugar, de negação do local de "vida besta" em que vive o garoto. A leitura, como um navio ou um voo, seria a possibilidade de deslocamento, em capa vermelha, cor nobre e chamativa, ou uma esvoaçante capa-vestimenta, distinta da indumentária do dia-a-dia, talvez até a aventureira capa-e-espada. A escolha de Júlio Verne, aqui - e não de Robinson Crusoé - aponta para essas leituras de iniciação também como desejo imaginoso de futuro, de mundos fantásticos, diferentes da vida comezinha. Verne é notoriamente um autor de livros em que assoma a viagem ao inacessível ou imaginário - o fundo do mar, o centro da terra, a ilha misteriosa, a lua, ao redor do mundo - que oferece ao menino leitor o fantástico para além da vida dos campos da pequena Itabira. No entanto, é notório já aí, nessa elaboração da memória, que o espaço da leitura desejada não é o espaço da escola - pois para livro escolar, o que recebe o garoto nada mais é do que um manual de Cultura dos campos - ironia residente justamente em ter seu acesso à discussão de cultura apenas naquilo que remete ao mundo rural em que vive, ou seja, os cultivos de alimentos e pastagens para gado. Ironicamente, sua sede pelos bens culturais, que reaparecerá na relação com a biblioteca do pai, tem por contrapartida apenas a cultura em seu sentido originário, o cultivo dos bens para o alimento do corpo, pastos de cria, pastos de engorda. O menino que lia a história de Robinson Crusoé, sem saber "que sua história era mais bonita que a dele", que sonha voar com Verne, talvez até a lua, é o mesmo que sonharia, se rei fosse, baixar um decreto que obrigasse este Assis (o Joaquim Francisco de Assis Brasil, e não o Machado) a ler sua própria obra. Destarte, o contraste presente na memória de seu processo de iniciação literária é - e já no menino que estudava no início do século passado - o do descompasso entre a leitura desejada e a leitura - ainda que não literária - imposta pela escola. Vive no contraste entre o chamado do chão - dos pastos que fecham o poema - e o voo de capa, no alto do poema.

A seguir, no mesmo livro, outras figurações da relação do menino com a leitura na escola aparecem. Quando pensa em elaborar seu Primeiro jornal, com Amarílio, o "incessante criador" colega de escola, é agora o menino que diz não conseguir escrever: 
Por mais que me coloque em transe literário e force a mão e atice a chama de meu peito, não consigo imitá-lo. Em lugar de escritor, na confusão da ideia e do vocabulário, sou apenas constante e humilhado leitor. ${ }^{3}$

Ao olhar o menino de escola, a memória vê ali um leitor humilhado, ainda que constante. O escritor é aí um leitor, fundamentalmente, algo como uma escritura resignada, e não a figura inspirada pelo transe sobrenatural, romântico de chama ao peito, imitador do amigo. Não há musa nem inspiração, mas, no paradoxo de dizer que não pode escrever, escreve; e mesmo ao olhar a cena de escola, escreve no presente - estoicamente, é um leitor prostrado pelo peso daquilo que lê; é ainda o menino de escola, diante dos exercícios de escrita em que se lhe põem o passado - ou os colegas - como medida. Em lugar da imitação - algo pelo qual a escola em muito prezou, e muitas vezes ainda preza. De toda forma, se na "iniciação" seria possível pensar qualquer assinalamento iniciático, que levasse aos voos, como algo restrito àqueles que passam por um rito, o comezinho da cena escolar é aquilo que barra a experiência do transe, do êxtase, ou ainda, devolve dessa possibilidade apenas o que ela tem de mais monástico: a constância, a devoção, a humilhação.

A sequência de aparições da leitura na infância, e na escola virá com o desejo de um objeto elevado, um presente a ser pedido ao pai, no poema Biblioteca verde. O garoto pede ao pai que compre a "Biblioteca Internacional de Obras Célebres", vetusta coleção de "só" 24 volumes encadernados em percalina verde, tecido de algodão forte e lustroso, "cristal de fluida transparência", que aumenta a imponência do material. No poema, o pai solicita a um coronel no Rio de Janeiro que mande a preciosidade, "tamanho universo", com muito cuidado - e além do trem de ferro, é um burro de carga que traz o "peso" da coleção. Do menino que tateia o livro, segue-se o menino que pas-

3 ANDRADE, Carlos Drummond de. Primeiro jornal. In: Nova reunião: 23 livros de poesia, op. cit., p. 604. A respeito desse poema, Maria Antônia Ramos Coutinho afirmará que "Como se vê, o "humilhado leitor" se propõe, no passado rememorado, como "em lugar de", no caso específico "em lugar de escritor". Forja-se um mecanismo de substituição em que a leitura se revela como um desejo de escrita, uma forma de igualmente escrever e de o sujeito se inscrever no mundo da criação literária. Drummond revela-se, assim, um leitor potencialmente escritor, e um escritor que se concretiza pela atividade vicária da leitura. Evidencia que ler e escrever são tarefas que remetem uma à outra, que se suplementam, portanto. A leitura ocupa o espaço do vazio e da falta que a linguagem do outro, expressa no "Primeiro Jornal", supre, enquanto o gesto leitor drummondiano se nutre dos escritos alheios." COUTINHO, Maria Antônia Ramos. Em lugar de escritor, humilhado leitor? In: DIAS, Cleuza Maria Sobral; PERES, Lúcia Maria Vaz (Org.). Territorialidades: imaginário, cultura e invenção de si. Porto Alegre: EDIPUCRS / Natal: EDUFRN / Salvador: EDUNEB, 2012, p. 102. 
seia pelas imagens de lugares distantes e figuras mitológicas, algumas delas nuas (para seu espanto), e novamente o livro é o espaço do distanciamento imaginário da vida besta tão próxima. Vozes da mãe, do irmão, chamando o menino que não dorme, leitor contumaz, se sucedem como queixas, como ameaças, como acalantos. $\mathrm{E}$ a isso tudo ele assim resiste:

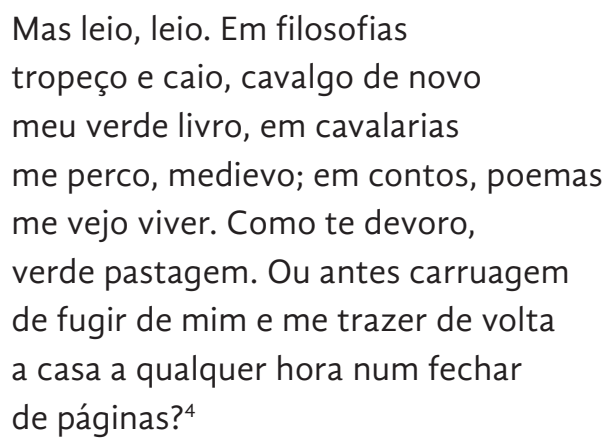

A leitura, alegoricamente, é aí pastagem (outros pastos, que não os incômodos do livro escolar), além de carruagem - novamente, possibilidade de deslocamento para se ver viver em contos, poemas, em textos - em algum lugar além e fora de onde estava, como possibilidade de fugir de si e se trazer de volta a casa (percurso, aliás, análogo ao próprio movimento da poesia de Drummond na saída e retorno para a casa). Todavia, permanece a sensação do movimento: o livro é cavalgadura, é carruagem que permite fugir de si - a experiência do êxtase, do ser-outro - e poder voltar a si num fechar de páginas. É no livro que é possível "se ver viver"- ao passo que ao mundo físico oferece o desejo do poder entrar nesse universo medievo, afundar no conto, se fazer poema. Na dimensão das frases, em seu enjambement cavalgado entre os versos, o desejo desse movimento, marcado na repetição do "leio, leio": fundamentalmente, nas três passagens em que é rememorado aqui o menino leitor Drummond, a leitura literária é pensada em oposição à estagnação dos campos, da "vida besta": é a possibilidade de se pensar como devir, e não mais como fixidez.

Ora, caberia pensar em relação a Drummond o mesmo paradoxo que se faz entre suas leituras espontâneas e o livro escolar. Se a escola não se configura como o espaço da iniciação literária do menino, o que dizer de como se faz a iniciação literária das crianças e dos adolescentes na escola? Da maneira como ainda está configurado o ensino básico, nos primeiros momentos

${ }^{4}$ ANDRADE, Carlos Drummond de. Biblioteca verde. In: Nova reunião: 23 livros de poesia, op. cit., p. 605. 
da formação, há certa labilidade nos currículos para escolhas de repertório, e importa a formação do leitor e a leitura prazerosa, buscando harmonizar com o horizonte de desejos do alunado, a entrada no Ensino Médio é marcada por uma virada na abordagem dos textos literários na escola. Notoriamente, o que ainda se encontra nos materiais didáticos e programas escolares é muito mais história da literatura do que literatura propriamente dita; ou ainda, substitui-se ao contato com textos literários alguma narrativa ou conhecimento sobre alguma literatura, ou ainda, um repertório validado institucionalmente e não muito variado - amplamente fragmentário e de alguma maneira monumental, centrado no conhecimento de alguns fragmentos do que foi escrito por grandes nomes. Em não havendo condições de vencer a tradição - seja pela sua dimensão, seja pela complexidade de sua linguagem, seja por contrastar diretamente com gostos formados por cinema hollywoodiano, o primado de uma linguagem mais literal dos best sellers ou referências que passam longe das escolares - os materiais se contentam com seus farrapos, tomados aos pedaços, para cumprir alguns exercícios, pesando mais por vezes na análise linguística desses fragmentos do que nas histórias que contam ou na diferença radicada no trabalho de cada escritor e de cada tempo com a linguagem. Ao fim de tudo, se há listas para os exames que serão feitos, a própria leitura das obras das listas vai sendo suplantada por resumos esquemáticos ou vídeos explicativos, que se provam relativamente eficientes para provas em que a experiência leitora é soterrada pelo mesmo perfil de resposta padronizada que os materiais ensinam a dar - e a cobrar.

Os livros escolares de hoje são filhos das antigas antologias ${ }^{5}$ escolares. Magda Soares, em Português: história de uma disciplina curricular, ao traçar o percurso de consolidação dos saberes escolares que constituem o que seja es-

\footnotetext{
${ }^{5}$ Vale lembrar também que a primeira antologia conhecida da literatura brasileira foi publicada em 1850, em Lisboa, pela Imprensa Nacional, por obra de Francisco Adolfo de Varnhagen, Visconde de Porto Seguro. O Florilégio da poesia brasileira adota o critério cronológico e procura fazer a seleção "do que de mais americano tivemos" na poesia brasileira, em movimento afinado com a invenção de um passado nacional no bojo do nosso Romantismo - e que repercute no primado do que se encontra como repertório escolar até hoje. Tratava-se, pois, de dar certidão de nascimento não só à nação - a tematização do índio, a questão da carta de Caminha - mas também ao passado literário. (VARNHAGEN, Francisco Adolfo de. Florilégio da Poesia Brazileira. Tomo I. Lisboa: Imprensa Nacional, 1850). Aponta-se também que participa de movimento semelhante o Resumo da história literária do Brasil, publicado por Ferdinand Denis em 1826, que faz considerações sobre o caráter que deve a poesia assumir no Novo Mundo. É preciso notar que, por mais que seja o primeiro documento a separar a literatura produzida no Brasil da de Portugal, embora a ponha numa sequência daquela, como aponta Maria Helena Rouanet, é, na visão de Candido, ali que se estabelece a "carta genealógica aos jovens". Trava-se, pois, também em torno desse documento, uma discussão consubstanciável entre origem e começo.
} 
tudar Português na escola atualmente, aponta para a construção da disciplina a partir de três pilares: a Gramática, a Retórica e a Poética; oficialmente, é a partir de 1871 que por decreto imperial se cria no Brasil o cargo do professor de português, que agregará o ensino dos saberes dessas três grandes áreas. A autora aponta que ao menos até os anos 40 do século $X X$ basicamente foram esses mesmos os conhecimentos trabalhados na disciplina, pensando-se justamente as normas e padrões do bem falar e do bem escrever. Isso, fundamentalmente, porque não se altera até aí o público a que era voltada a educação escolar, ou seja, apenas as elites frequentavam a escola; e à literatura, cabia a exemplaridade, ou seja, representar e ser estudada como artifício para "escrever bem". Magda aponta, a respeito das coletâneas de textos, que

[...] limitavam-se elas, no início do século, à apresentação de trechos de autores consagrados, não incluindo, em geral, nada mais além deles (nem comentários ou explicações, nem exercícios ou questionários), o que evidencia a concepção de professor da disciplina português que se tinha à época: aquele a quem bastava que o manual didático lhe fornecesse o texto, cabendo a ele, e a ele só, comentá-lo, discuti-lo, analisá-lo, e propor questões e exercícios aos alunos. [...] Várias seletas estiveram presentes nas escolas brasileiras no final do século XIX, e até as primeiras décadas do século XX; muito usados foram os volumes da Selecta nacional, do filólogo português Caldas Aulete, mas a seleta que realmente dominou o ensino médio brasileiro durante a primeira metade do século foi a Antologia nacional, de Fausto Barreto e Carlos de Laet; publicada em 1895, dominou, por mais de 70 anos, o ensino de Português, tendo sido sua última edição, a 43ª, já em $1969 .^{6}$

A diferença principal que se estabelece, a esse respeito, é o fato de que não são apenas seleções de textos, mas substituem o próprio trabalho de interpretá-los. Por um lado, docentes com formação e condições de trabalho cada vez mais sucateadas acabam por tê-lo como facilitador de sua abordagem em sala de aula. Como exigir que um professor que passa mais de 30 horas em sala de aula, trabalhando muitas vezes em escolas sem biblioteca e com restrição no número de cópias que pode fazer leve repertório diferenciado até seus alunos? Por outro, temos o discurso de que o livro didático é um direito do aluno - direito que por sua vez leva grande monta dos recursos para educação

\footnotetext{
${ }^{6}$ SOARES, Magda. Português: história de uma disciplina curricular. In: BAGNO, Marcos. Linguística da norma. 2. ed. São Paulo: Loyola, 2004, p. 166. Magda não deixa de apontar que é sintomático, a partir dos anos 50, com a universalização do acesso ao ensino e o declínio do prestígio social do profissional docente, bem como a crescente ocupação desses postos por filhos das classes populares, e não mais por eruditos vindos das elites devotados ao estudo de língua e literatura, começam a aparecer cada vez mais "apoios" à elaboração da aula dos professores no próprio material, como exercícios e notas com indicações metodológicas.
} 
diretamente do Governo Federal para certos grupos editoriais - alguns dos quais crescem e viçam basicamente a partir dessas vendas, que atraem, inclusive, interesse de capital estrangeiro. Note-se ainda a recente suspensão do Programa Nacional da Biblioteca Escolar, que por bom tempo ajudou a prover as escolas de algum acervo. Agora, a opção do governo é justamente incorporá-lo ao Programa Nacional do Livro Didático, talvez diluindo o acesso ao livro de literatura num difuso programa de material escolar. É preciso registrar que a escolha do livro do PNLD é um imperativo - mesmo que a escola pública ou o professor não queira escolher, por razões políticas, didáticas, quais sejam, o livro, qualquer um dos aprovados na seleção prévia, é considerado direito do aluno e será enviado.

O dilema que se me colocou ao pensar minha intervenção neste evento a partir do lugar que ocupo foi: se no poema Drummond fala da iniciação literária da persona poética que construiu, ou - correndo o risco - do menino "Drummond", qual seria a iniciação literária dos meninos em Drummond? No jogo entre a literatura como desejo de viagem, de fuga da ordem comezinha e um repertório escolar(izado) como a aridez dos manuais de que fala o poema, que contraste se faz entre o mundo sonhado e o mundo "prático" nas nossas antologias? Dito de outro modo: na medida em que o lugar do livro didático é por vezes o que apresenta muitas das referências as quais os estudantes não vão sozinhos, ou não thes dizem outra coisa senão o serem de escola ou que aparecerão, possivelmente, em um exame como o $\mathrm{ENEM}^{7}$, que tipo de iniciação literária a um escritor multifário como Drummond encontramos atualmente nesses livros? Por fim: se o papel de tal livro também é preparatório - para qualquer experiência extraescolar, para que a leitura prepara, no caso da escolarização da literatura?

Se Júlio Verne poderia se mostrar como o propulsor da leitura como viagem à fantasia, como voo e navegação, para um Drummond leitor do início do século $X X$, para um leitor do início do século $X X I$ a leitura se configura como algo distinto; com uma sensibilidade forjada por experiências muito distintas, a maioria delas distantes do próprio livro. O espaço da leitura "por obrigação" por vezes é o único da formação de certo repertório, canônico e validado, o

\footnotetext{
${ }^{7}$ Nunca se sabe que autor pode aparecer ou não na prova, ainda que Drummond seja um dos mais frequentes. De todo modo, exige-se que o aluno tenha condições de interpretar e responder sobre quem quer que seja e sobre qualquer texto aquilo que se espera que diga. Para muitos - e por que não dizer, para o atual Ministério da Educação, o papel instrumental da escola seria preparar para isso - ou para acessar o mercado de trabalho antes disso, não passando pelo ensino superior.
} 
qual não pode, por outro lado, prescindir de dialogar com o escolhido, sob pena de relegação total a nada mais do que lista para exames. O movimento de renegar o livro escolar - ironicamente chamado Cultura dos campos (em que os termos são do étimo agrário, não apenas, mas fazem pensar em certa cultura, a escolar) - é também, paradoxalmente, o movimento de inscrever; o livro de escola pode ser o repertório recusado, mas de alguma maneira, ele se inscreve na iniciação desse sujeito (que é um movimento - e por isso mesmo um impossível, uma vez que sempre haverá uma nova divisão "no meio do caminho": "O paradoxo da história (literária, cultural, qualquer que seja) é a ilusão de movimento que é, ao mesmo tempo, ilusão interpretativa", nos ensina Antelo nas Aporias da leitura. ${ }^{8}$ Por fim: inserida na Biblioteca verde, pode a poesia se converter em desejo para além da obrigação, amargando o difícil lugar de já ser a pouco procurada entre os gêneros literários?

Digo isso pensando fundamentalmente no Drummond poeta. Certamente, em várias fases de sua formação antes do Ensino Médio, um estudante encontra textos de Drummond - crônicas, contos, talvez mesmo vários de outros seus poemas, não tratados, ainda, como peça de uma historiografia da literatura. Na sistematização típica do Ensino Médio, a cronologia da literatura nacional é ainda o critério organizativo de maior vigência - o que já nos diz muito sobre a concepção que se tem do próprio objeto de ensino, linear, cronológica, evolutiva, narrativizada para construção de um ideário de nação ou de participação, como se verá a seguir - e, por isso mesmo, feita a partir de significativas exclusões. Como já vimos, essa mesma forma de apresentação tem pelo menos dois séculos e não se modifica, apresentando pequenas e tímidas variações. Se sobrar o tempo que nunca sobra, lê-se o tempo presente.

\section{COLEçÕES}

Nessa visão linear, Drummond é apresentado no terceiro ano do Ensino Médio, no qual o foco fundamental das coleções, com poucas diferenças entre si, parte do início do século XX. Minhas reflexões e apontamentos sobre

\footnotetext{
${ }^{8}$ Ao montar uma perspectiva de ensino em que o tempo linear e sucessivo pauta o olhar para a pedra no meio do caminho - a literatura -, investe-se na perspectiva de que há movimentos literários dados no tempo. Antelo, ao analisar o Áporo drummondiano, nos ensina, ao justapor o poema No meio do caminho, de Drummond, ao paradoxo de Zenon, que não há, a rigor, movimento, nem se percorre o caminho, pois, em sendo o tempo uma "divisão infinita de instantes fugitivos", e em sempre havendo um meio do caminho, há sempre um ponto em que o movimento cessa, e o que conhecemos como história é uma ilusão interpretativa de justaposição de momentos. O meio do caminho seria, pois, o ponto da apatia, isto é, da literatura. ANTELO, Raúl. A aporia da leitura. Ipotesi, v. 7, n. 1, p. 35, 2003.
} 
formação desse repertório - por vezes criticada mesmo dentro dos cursos de Letras em relação ao alunado que recebe - vão tratar de algumas das coleções cuja implementação iniciará no próximo ano, e que serão utilizadas nas escolas entre 2018 e 2020: Ser protagonista (SM, vários autores; editora de grupo espanhol, não traz o crédito da autoria na capa); Linguagem e interação (Faraco, Moura e Maruxo Jr.; Editora Ática); Português - Contexto, interlocução e sentido (Maria Luiza e Maria Bernadete Abaurre e Marcela Pontara; Moderna); Se liga na língua (Cristiane Siniscalchi e Wilton Ormundo, Moderna); Novas palavras (Emília Amaral, Mauro Ferreira, Ricardo Leite, Severino Antônio, FTD); Português contemporâneo: diálogo, reflexão e uso (Carolina Dias Vianna, Christiane Damien e William Cereja, Saraiva). Minha leitura dos fragmentos dessas coleções - ela própria fragmentária e falha - vai em dois sentidos de como se dá a abordagem de Drummond: primeiramente, o "serviço historiográfico" de inserção geracional, qual seja, a ilusão que nos dão de encaixe de Drummond em uma categoria, chamada "fase", "geração" ou outra produção narrativa de uma produção autonomista da "forma" Drummond, ou seja, de um sujeito funcionário público estatal em que desperta "progressivamente" uma "consciência social" diante da guerra. Nítido será, primeiro, que uma mesma narrativa crivada de clichês que criam uma forma-encaixe para a peça Drummond. A seguir, apontamos justamente quais são os textos que constituem o repertório nitidamente limitado de um Drummond escolar.

\section{GERAÇÃo?}

É notório que por vezes a análise não poderá prescindir, de certa maneira, da descrição. Além disso, nas obras analisadas, ideias como "fase" ou "geração" modernista ou "de 30" são ainda operativas em praticamente todas as coleções. A redução didática depõe sobre a solução cronológica de abordagem, em que se subsumem singularidades na leitura que reduzem um sujeito ao fazer parte de certo "espírito de época". Essa mesma leitura é tributária da própria história de nossas antologias e, também, do gesto de autoarquivamento operado por crítica modernista do Modernismo, que, ao narrar sua história, construiu seu cânone. Ao se tomar a Semana de 22 como espécie de marco (re)inaugural de uma ficção do nacional radicada e imaginada a partir de São Paulo, a vinculação de escritores díspares - e por que não dizer, contraditórios - a essa mesma narrativa, em que pesem diferentes concepções sobre o que seja literatura, reduz forças à forma, ao retrato de uma geração; digamos que surja aí o que Antelo, ainda na análise feita em A aporia da leitu- 
ra, chamou de tendência sociologizante que procura "escrever uma biografia política nacional que devolva um sentido extraviado da vida".

Seria interessante frisar alguns dos termos em que essa narrativa aparece. Para a coleção Se liga na língua, a poesia da "segunda fase" do Modernismo é resumida como "expressão do mundo" - casamento entre o "vasto mundo" e certa leitura de matiz romântico que ainda acredita ser o mundo algo capaz de se expressar, ou ainda, haver na linguagem algo que conseguiria alçar a representação do mundo, ou ainda, obturar o vazio do sujeito na medida em que esse seria capaz de expressar o irrepresentável que um significante como "mundo", em sua pretensão de universalidade, poderia representar - mesmo para o poeta que via em Raimundo rima, no coração mais vasto que o próprio mundo. A coleção apela, ainda, à narrativa do próprio Mário de Andrade em sua célebre conferência de 1942, intitulada O movimento modernista, clássica peça do revisionismo modernista, apresentada justamente 20 anos depois da Semana e 3 anos antes da morte de seu autor, em que a "geração" de Drummond surge como "preocupada com problemas que não preocupavam em 22" - o que vem a corroborar a sempre presente narrativa do poeta que vai tomar viés mais "social", "inconformada", lida mesmo como oposição "socialista" a Getúlio. É no mínimo curioso que se opere essa polarização, na medida em que vários dos intelectuais modernistas acabaram trabalhando para o Estado Novo; o próprio Drummond, por exemplo, ao lado de Gustavo Capanema, no Ministério da Educação e Saúde. ${ }^{9}$ Não deixa de ser digno de nota que se peça que o estudante "imagine" o ano de 1930 com os lançamentos de Drummond, Bandeira, do próprio Mário e de Murilo Mendes; haveria que se perguntar o que representam esses nomes ou os títulos por eles publicados em 1930 para quem os desconhece. Ou ainda: que imaginário formado sobre o período tem o estudante para recriar essa cena; ou mais: qual o impacto que esses livros de fato tiveram quando de seu lançamento, e quanto de sua importância foi construída posteriormente pela crítica. É notório que Drummond, por exemplo, compilou a polêmica de seu próprio "poema da pedra", que sozinho rendeu fortuna para um livro inteiro; mas quanto um livro de poemas pode ter de impacto no imaginário de um jovem contemporâneo?

\footnotetext{
9 Seminal a esse respeito é Literatura em revista, livro resultante do doutorado de Raúl Antelo, publicado em 1984, no qual, a partir da análise de três revistas que circularam no período do Estado Novo - Cultura Política, Revista Acadêmica e Literatura - de diferentes campos do espectro político, marca-se, especialmente a respeito da primeira - publicada pelo Departamento de Imprensa e Propaganda getulista - o pacto com alguns dos modernistas, o que marca o claro flerte que qualquer das hostes mantém com o que o autor chama "imperativo da ordem”. (ANTELO, Raul. Literatura em revista. São Paulo: Ática, 1984. (Ensaios, 105))
} 
Por fim: formar conjunto desses diferentes autores não se faz possível a não ser por generalizações como "estilo misto" e "abordagem de temas existenciais", expressões que ao tentarem fazer conjunto do desconjuntado, acabam por nada dizer.

De sua parte, em Novas palavras, o capítulo chama-se "A segunda geração modernista: poesia" alia a visão evolutiva do tempo ao nacional-desenvolvimentismo para dizer que a produção de 30 "assimilou elementos da primeira e ultrapassou, se universalizando, sem perder a medida do nacional". Nesse sentido, a visão do tempo como progresso presta-se a uma redução da produção da década de 20 aos temas "nacionais", que, no "progresso" dessa "tomada de consciência" (no que poderíamos encontrar os ecos da leitura de Candido em textos como Literatura e subdesenvolvimento) chegar-se-ia ao "universal", ou a universais, no que construiria "régua e compasso que duram até nossos dias". Com isso, introduz texto de Nelson Ascher (datado de 2007) intitulado O fim da poesia?, em que o autor pondera a forma fixa como um pacto de leitura que dá ao leitor a certeza de estar diante da poesia - e seu abandono como o desafio de saber se se está diante da leitura de um poema ou não (pergunta que reverbera em sala de aula). Em que pese a introdução ter sido feita pela narrativa evolutiva, deslocar a pergunta para "o que é a poesia?" pode representar artifício interessante, em especial em tempos obscuros nos quais o senso comum tem paulatinamente procurado ditar sua boa-moça visão do que seja arte - recrudescendo em direção a concepções conservadoras que por um momento pareceram, para nosso desesperado equívoco, ultrapassadas).

Na narrativa criada por Ascher e replicada no livro, "buscando competir com o noticiário e as manchetes jornalísticas, [os poetas] recuperariam os leitores que perdiam com o que, embora chamado de experimentalismo, era antes a quebra de um contrato secular". Por sua vez, "poetas da geração seguinte recuaram diante da possibilidade de alienar de vez o público restrito que a poesia ainda possuía"10, e nisso, sua ponderação maior é a da relação entre poesia e público, a mesma e angustiante relação que permeia a própria abordagem do poema em sala de aula - quando ainda prevalece no senso comum a ideia de que poesia é escrever algo de bonito ou rimado em que eventualmente se veja alguma mensagem de moral edificante, ou então, que "comunique" algo. Pensando na tríade do sistema candidino, a pergunta que

${ }^{10}$ ASCHER, Nelson. O fim da poesia? In: AMARAL, Emília; ANTÔNIO, Severino; FERREIRA, Mauro; LEITE, Ricardo. Novas palavras. v. 3. São Paulo: FTD, 2016, p. 77. 
surge é se "É possível reverter essa queda e tornar a poesia novamente importante e popular?" (e aí em parte se pondera o papel do artista e em parte o do público - julgado "mais preguiçoso e sedado" na contemporaneidade, em juízo que ignora as formas da poesia que caem no gosto de público mais amplo, mas não do crítico). Para além de inserida num esquema comunicativo, a literatura é ainda pensada como "expressão do momento", e Alguma poesia é dado como marco inaugural de uma geração, destacando-se, novamente, a incorporação das "reivindicações e conquistas de 22": "conciliação com a tradição no Neossimbolismo de Cecília, no Neoparnasianismo de Jorge de Lima e no Neoromantismo de Vinicius". Em suma, o livro de Drummond, sobre o qual se diz que abre uma nova geração é, por outro lado, o porteiro de vários "neos", por isso, menores do que a figura de Drummond (como se houvesse a necessidade de medir figuras). Por fim, novamente fazendo valer a narrativa sociologizante que hegemonicamente foi construída em torno da poesia de Drummond, afirma-se, com imperativo funcionalizador da arte: "Os poetas da geração de 30 têm consciência de que a problemática do mundo que vivemos é de natureza política. Portanto, está diretamente ligada com o sistema capitalista, suas desigualdades, suas contradições, seus mecanismos de opressão e de desumanização, que a poesia e a arte precisam denunciar." Tal produção progressiva do denuncista passaria, na construção feita pelo livro didático, por três fases da "escavação do real" feita por Drummond, em apresentação panorâmica, com o fácil intertexto de uma fase "Mundo mundo vasto mundo" (desde Alguma poesia, com o surgimento do gauche; concentração no homem que não se torna escapista pela ironia); passaria pela "Se eu me chamasse Raimundo, seria uma rima, não seria solução" (no que estaria a figuração do abandono por Deus; da aporia da pedra no caminho; do "e agora, José"; da sensação de beco sem saída; "marchar para onde?"; do coração que se iguala ao mundo para reunir poesia e vida); e por fim, do "Coração menor que o mundo", em que ganha destaque em A rosa do povo, livro que o tornaria, para os autores, o maior lírico moderno brasileiro. E finda a poesia de Drummond aí, na metade do século.

A metáfora da escavação é ainda corroborada a partir da citação de Bosi:

"Tanto na poesia de desnudamento dos grandes dilemas, das questões humanas que atravessam todos os tempos, todas as idades, 'revelando o vazio à espreita do homem, no coração da matéria e da história' (BOSI, Afredo. História concisa da literatura brasileira. São Paulo: Cultrix, 1978) quanto nessa vertente concreto-formalista, sua tendência de ir além das superfícies para 'escavar' o real reúne-se à constante exploração das potencialidades da linguagem poética. ${ }^{11}$

${ }^{11}$ AMARAL, Emília et al., Novas palavras, op. cit., p. 89. 
Tem-se aí, na citação apresentada e na maneira de ligá-la à narrativa que o próprio livro faz, mais uma das manifestações do que Raúl Antelo assinala, ao propor uma leitura contra-modernista do Modernismo em sua leitura do Áporo, como a não inocência de significantes como "flor" e "povo", "cultura" e "realidade": "a rosa do povo equivaleria a afirmar o sublime da realidade, fazendo en passant uma aposta sub-reptícia em direção à superioridade da cultura, entendida como cultura unionista, de comunhão cultural." ${ }^{12}$ Daí, pois, o ser apresentada como ponto máximo, mesmo sendo o meio do caminho.

Por sua vez, o que subsume a segunda geração, em Português: contexto, interlocução e sentido (singular!), de Abaurre e Pontara, é a junção "misticismo e consciência social". A coordenação aditiva que simplesmente procura casar certas tendências religiosas de poetas como Murilo Mendes e Jorge de Lima talvez negligencie a mística propriamente cristã da própria narrativa da "tomada de consciência social", ou espécie de emancipação da consciência da vida besta para o "universal" a partir da experiência da guerra. Nesse sentido, as autoras destinam grande parte da abordagem a uma retomada historiográfica da cena mundial da década de 40, em especial a Segunda Guerra Mundial (usando o mural Guerra, de Lasar Segall, como ilustração), para atribuir a ela a poesia, na forma de determinação: "A instabilidade social e política relacionada a esse momento faz com que surjam, na literatura, propostas e diferentes modos de interpretar a realidade e de responder às grandes questões humanas."13 Isso seria, para elas, a "consolidação de uma estética" em que os autores "passam a refletir sobre o mundo contemporâneo" (como se antes não o fizessem). A ideia de um "projeto" literário de uma "segunda geração" (em que se ignora a continuidade da produção dos que surgiram anteriormente) não consegue se fazer em mais do que o problema da "consciência", o que redundaria na própria leitura da poesia como expressão de uma visão de mundo "consciente" - e aí, caberia a pergunta "por que a poesia?".

O livro assume a tese de que há um "projeto literário" da segunda geração modernista, mas novamente, ele é "refletir sobre o sentido de estar no mundo" - o que seria salutar se não pensássemos no próprio Borges definindo a filosofia como um ramo da literatura fantástica, ou como se "estar no mundo" fosse uma categoria resumível a um momento histórico. Passa-se a uma análise de agentes do discurso; condições de produção e de circulação (utilizando

${ }^{12}$ ANTELO, Raúl, $A$ aporia da leitura, op. cit., p.38

${ }^{13}$ ABAURRE, Maria Bernadete; ABAURRE, Maria Luiza; PONTARA, Marcela. Português: contexto, interlocução e sentido. 3. ed. São Paulo: Moderna, 2016, p. 62. 
terminologia própria da abordagem da análise do discurso/linguística, muito mais do que dos estudos literários), focada nas trocas e nas leituras de uns pelos outros (menos do que nas permanências da tradição visíveis nesse discurso, uma vez que elas não convêm à história contada). Drummond é evocado para pensar a relação entre arte moderna e público - e sua incompatibilidade: "a eliminação do assunto" como destino de sua poesia, na narrativa construída nesse livro didático, não seria um flagrante contrassenso com a "preocupação social"? O que seria um público que dá atenção "ao assunto"? Por fim, nessa discussão sobre "gosto do público", afirma-se que este teria sido despertado por "as experimentações estéticas" darem lugar "às indagações humanas".

Em outros dois dos livros selecionados, a unidade em que surge a abordagem de Drummond é pensada em confluência com outros conteúdos, não necessariamente do campo da literatura, de forma mais ou menos articulada. William Cereja, Carolina Dias Vianna e Christiane Damien vão juntar Drummond - sempre poeta, pois o máximo que se trata sobre seus outros escritos é de citá-los em listas de obras e anos separadas por gênero - com cartas argumentativas e torna-lo pretexto para discussão sobre colocação pronominal. Novamente, a poesia é tratada como reflexão sobre o "estar no mundo, voltada muitas vezes para questões sociais, mas também para questões filosóficas, existenciais, espirituais e amorosas"14, no que se repete a generalização dos temas (que são atinentes à poesia de qualquer tempo, porque extremamente generalistas) e se negligencia a dimensão de intervenção da literatura como suplemento de sensibilidades. Novamente, a narrativa da evolução terá de dar aos poetas de 30 a medida das formas, apontando para a "manutenção de conquistas formais", mas "retomam alguns procedimentos formais antes combatidos pelos modernistas, como o verso regular, o soneto e outras formas tradicionais da poesia" - ao que se segue a lista de poetas: Drummond, Cecília, Vinicius, Jorge de Lima, Murilo Mendes e Mário Quintana. Sobre a obra de Drummond, ao longo de mais de 50 anos, novamente a visão da ideia de reflexo, em que se enfatiza sempre uma espécie de justificação das essências ou de determinação do social sobre o literário: “[...] foi se modificando, refletindo os fatos histórico-sociais, porém nunca deixou de apresentar certos traços que lhe foram essenciais, como a reflexão existencial e a ironia".

É nesse sentido que os autores reproduzem a divisão das fases: (1) Alguma poesia e Brejo das almas: influência dos modernistas de 22; marcados pelo ex-

${ }^{14}$ CEREJA, William; DAMIEN, Christiane; VIANNA, Carolina Dias. Português contemporâneo: diálogo, reflexão e uso. v. 3. São Paulo: Saraiva, 2016, p. 160. [Grifo meu]. 
perimentalismo estético, "apesar disso, apresentam uma profunda reflexão sobre o 'estar no mundo', em uma perspectiva mais individualista e pessimista, revelando um claro sentimento de mal-estar, desagregação e inadequação". (2) Sentimento do mundo José, A rosa do povo: mudança de perspectiva; temas sociais e universais, sentimento de esperança e união entre os homens; (3) Claro enigma, Fazendeiro do ar e A vida passada a limpo - retoma a postura reflexiva e filosófica das obras iniciais, traços de desilusão e pessimismo; e a "fase final" de Boitempo, Corpo e Amar se aprende amando: "temas universais como a memória, o tempo, o amor e o erotismo".

É patente que a aposta é sempre a de justificar alguma espécie de "utilidade" para a literatura por poder representar uma "reflexão" sobre algo vago como um "estar no mundo" - ou estar na história, tomando consciência de seu papel nela, desconsiderando-se o viés da experiência estética pela necessidade da prévia justificação narrativa do porquê estar lendo aquele homem para além da reiteração de sua "importância" no cânone. Nesse sentido, curiosa é a aposta de Linguagem e interação, de Faraco, Moura e Maruxo Jr., em que Drummond aparece em uma unidade sobre Carta pessoal, sem que, no entanto, se leia qualquer de suas cartas. No meio da unidade, deparamos com: Segunda fase do Modernismo brasileiro - poesia, e, após lermos José, há a curiosa renúncia à narração: "Pela grandiosidade e pela qualidade, sua obra não permite qualquer tipo de esquematização didática. Para compreender e, sobretudo, sentir a obra desse escritor, o melhor caminho é ler seus poemas. Aqui apresentamos alguns, de diferentes fases de sua obra." ${ }^{15}$ Ao fim do conjunto de textos, os autores, no entanto, afirmam uma narrativa, na medida em que dizem que "a poesia amadureceu, incorporando uma temática social mais densa". Com efeito, é importante que se diga, as operações de leitura é que apontarão para um caminho distinto do pensar a poesia - por vezes, fortemente subserviente, ainda, à gramática. Não há, além de tudo, aporias ou contrassensos nas leituras propostas; o Drummond do livro é uma versão em que se buscam não os limites da representação, mas a coincidência impossível e potencializada no campo poético entre representação e realidade. É preciso que se diga que, em poesia, a linguagem prolifera ao paroxismo da conotação, ao dispêndio que não representa, mas antes de tudo, desafia.

${ }^{15}$ FARACO, Carlos Emílio; MARUXO JR., José Hamilton; MOURA, Francisco Marto. Língua portuguesa: Linguagem e interação. v. 3. 3. ed. São Paulo: Ática, 2016, p. 229. 


\section{QUE REPERTÓRIO PARA QUE LEITURA?}

Talvez alguém pudesse dizer que não poderia ser diferente o repertório de uma primeira apresentação que não contemplasse, efetivamente, os que vieram a se tornar os mais conhecidos poemas de um poeta - reafirmando a ideia de que há textos mínimos. No entanto, com essa mesma ideia retorna-se à funcionalização da literatura no Ensino Médio escolar - os exames, as provas, em que prescindindo de peculiaridades ou da multiplicidade dos desejos, ou ainda, de escolhas de textos que possam fazer sentido para os grupos com os quais se trabalha. Restam roteiros - itinerários em que se faz acreditar que o mapa pode coincidir com o território.

No meio do caminho é, justamente pela polêmica que despertou, elemento corrente em boa parte das coleções. Em Ser protagonista, é usado como exemplo de uma "primeira fase" da obra "influenciada por Mário de Andrade", pelo "verso livre, coloquialismo e humor corrosivo. A coleção aponta para o incômodo gerado com a publicação na Revista de Antropofagia, destacando as repetições insistentes e o coloquialismo do verbo "ter". Visto como um apontar para a "falta de saída", o poema é aqui incluído como exemplar de uma "atitude reflexiva". Não muito diferente será o que se verá em Se liga na língua (que opta por explicar, nas indicações ao professor, as referências a Bilac e a Dante - indo na direção do que Magda Soares aponta ao observar que as indicações ao professor são crescentes para suprir a previsão das faltas na formação); em Abaurre e Pontara, também se pondera os dois lados da conhecida contenda em torno do poema; Cereja, a essa mesma leitura, soma a informação de que o próprio Drummond publicou o volume em que compilava a polêmica. Linguagem e interação o considera um "poema que anuncia a reflexão sobre os diversos obstáculos que o homem tem que enfrentar." De qualquer maneira, o que encontramos sobre o talvez mais célebre poema de Drummond é um interesse gestado, puramente, pela polêmica, e pouca discussão sobre o que seria "reflexão" ou "obstáculo" - menos ainda, talvez, para que o próprio estudante possa formular seu entendimento do poema, que no fundo, de crucial, como depõe a leitura de Raúl Antelo aqui já retomada, é tornado algo episódico - algo semelhante à hipertrofia de jornalismo de polêmica que vivemos.

Da mesma forma, em relação ao Poema de sete faces, sobrepõem-se à experiência de leitura do próprio poema interpretações já dadas: Se liga na língua, além de antecipar ao contato com o texto a leitura que faz do que seja o 
gauche, partindo, portanto, da interpretação para o texto e não o contrário, fará de Drummond "[...] ainda um poeta do modernismo heroico, mas já ligado à reminiscência familiar." ${ }^{16}$ Em seguida, leitura em um parágrafo, dos sentidos do que seria a "inadequação do eu" e da "mistura do 'eu ficcional com o eu real'" (essencializando uma das instâncias a partir da narrativa da história do poeta, ou ainda, acreditando que haja para o próprio poeta o acesso a um "eu real" que não seja ele próprio também representação ou ficção de si).

É recorrente, ainda, que se receba modelos interpretativos já prontos, como em Novas palavras, ao "pedir que se separem as sete faces do poema", ou criar proposições que já colocam a interpretação - metonímica, por exemplo - para ser apenas corroborada pela localização de elementos ("óculos", "bigode"). Entende-se, pois, que não se percebe aqui o texto como movimento sem fim, mas como finalidade de comprovar determinada leitura, ou ainda, a percepção de "figuras de linguagem" ou categorias e usos gramaticais coloquiais e formais. Ser protagonista opta por mostrar o intertexto com Até o fim, de Chico Buarque, em atividade suplementar. O poema que abre o primeiro livro de Drummond aparece ali como texto em que

\footnotetext{
O eu lírico se apresenta como um gauche, termo francês que significa 'esquerdo', 'desajeitado', e sugere seu deslocamento em um mundo habitado por semelhantes com quem não se comunica. Essa relação tensa e instável do eu com o mundo, marcada por momentos de aproximação e de distanciamento, é uma das principais marcas de sua poética. ${ }^{17}$
}

Isso se faz, além de tudo, sem apresentar o texto propriamente dito do poema, dando primazia apenas à interpretação dos autores e reiterando novamente a tese do caráter reflexivo, ou ainda, como unívoca uma armação de sentido que só poderia ser retrospectiva. No entanto, quem aí se reflete?

Para além dessas mais previsíveis seleções, outras tantas marcam a forte tendência à ênfase da poesia social em Drummond. São exemplares desse veio, por exemplo, Poema da necessidade (em Se liga na língua): "É preciso viver com os homens / É preciso não assassiná-los, / É preciso ter mãos pálidas / E anunciar o fim do mundo"; Política literária e um fragmento de Nosso tempo, além de Tristeza do Império e Morro da Babilônia (em Novas palavras), sempre com a ênfase de "localizar determinada fase" do poeta; A noite dissol-

${ }^{16}$ ORMUNDO, Wilton; SINISCALCHI, Cristiane. Se liga na língua. v. 3. São Paulo: Moderna, 2016, p. 96.

${ }^{17}$ BARRETO, Ricardo Gonçalves et al. Ser protagonista. v. 3. 3. ed. São Paulo: Edições SM, 2016, p. 100. 
ve os homens (de Sentimento do mundo, longamente enfocado por Abaurre e Pontara como representação da guerra - como surgirá a Carta a Stalingrado em Ser protagonista, em que se procura que o estudante consiga perceber fundamentalmente noite e aurora como metáforas, e perceber o elo do poeta com os tempos presente e futuro); Mãos dadas (exemplar de que a "função social do poeta como denunciar a opressão" - ler o tempo como sua matéria). É notório, pois, que Alguma poesia, Sentimento do mundo e A rosa do povo são as fontes privilegiadas pelos livros para sua abordagem do poeta.

Cereja somará o também bastante conhecido A flor e a náusea, buscando a caracterização do ambiente e do tempo do eu lírico, de seus desejos, do nascimento da flor, do "sentido maior para o nascimento da flor"; isso para depois partir para grande sorte de questões sobre colocação pronominal no poema (e a relação disso com a dicção da primeira geração), fazendo, portanto, com que o fim da interpretação seja mais um debruçar-se em questões de gramática do que em um sentido a priori já dado ao poema.

O caso de José e as inquietações sobre ele postas levariam ainda a observar que em um dos livros - o de Abaurre e Pontara - o título do poema surge alterado para "E agora, José", e este novamente trazido aos fragmentos - demarcando também o desapreço para com a verificação das fontes ou com o que diferentes títulos impactam no sentido de textos densos como poemas. Linguagem e interação, por sua vez, traz José completo, antes da apresentação do autor (a qual é novamente o box de dados biográficos com enorme ênfase para a cronologia de sua obra). Não seria desejável, pois, que todos esses poemas - ou problemas - pudessem ser apresentados em conexões que mostrem suas forças pulsantes, em especial em questões presentes, para que não se cristalizem como representação distante de um passado tanto mais remoto quanto mais o tempo se nos parece acelerado? Não seria o caso de que os estudos de literatura pudessem pensar antes séries de imagens do que "cromos da nação", como a fixação que surge pelo vulto desse certo Drummond?

É certo que ainda há outros textos de Drummond que fazem parte de uma ou outra seleção: seria possível citar aqui No exemplar de um velho livro (o "veIho livro" como figuração de "poeta maduro", "metafísico"), Mundo grande, Infância, Um boi vê os homens; Consideração do poema; Amar; Coração numeroso ou a Confidência do itabirano (texto que já foi matéria de uma questão do ENEM). No entanto, mesmo entre as sugestões de leituras complementares, dificilmente nos surge sequer a indicação de um livro inteiro do poeta; dificilmente, aliás, é possível pensar o objeto livro de poesia como um gênero a 
se trabalhar em sala de aula. O princípio topológico e nomológico do arquivo seleto dos poetas mortos que nos é dado basicamente parece servir sempre a outro propósito: apontar sempre a um lugar arquivado morto que não a poesia, e não ao pulsar de uma vida nos textos com que nos deparamos. O sentido está sempre dado para ser descoberto, adivinhado, com as respostas ao lado ou alternativas para conferir - nunca é movimento, nunca aparenta ser sem fim, nunca é ilusão.

\section{ILHAS}

Caberia por fim apontar que parte do que resulta na previsibilidade de tudo quanto eu falei é o divórcio paulatino em que se encontram recentes intérpretes da academia da discussão sobre ensino. Discute-se muito sobre as intransparências da linguagem, mas a própria relação da literatura com o ensino é no mais das vezes negligenciada, como se paradoxalmente fosse transparente, e deixamos que outros façam o debate sobre currículo, sobre escola, sobre o movimento de iniciação. Se se espera que outras visões de literatura entrem no choque de forças, proliferando as tensões típicas do campo e possibilitando o pensar além das fórmulas prontas em que se enclausura o passado, urge que também o campo dos estudos literários não se ilhe de pensar o ensino. Em tempos nos quais se pretende prescindir do pensar, ou prescindir da singularidade da experiência com a linguagem, com o poema, com tudo aquilo que não pareça pronto, talvez perguntaria Drummond, que certo dia imaginou sua ilha:

\footnotetext{
E por que nos seduz a ilha? As composições de sombra e luz, o esmalte da relva, a cristalinidade dos regatos - tudo isso existe fora das ilhas, não é privilégio delas. A mesma solidão existe, com diferentes pressões, nos mais diversos locais, inclusive os de população densa, em terra firme e longa. Resta ainda o argumento da felicidade - "aqui eu não sou feliz", declara o poeta, para enaltecer, pelo contraste, a sua Pasárgada; mas será que se procura realmente nas ilhas a ocasião de ser feliz, ou um modo de sê-lo? E só se alcançaria tal mercê, de índole totalmente subjetiva, no regaço de uma ilha, e não igualmente em terra comum? ${ }^{18}$
}

${ }^{18}$ ANDRADE, Carlos Drummond de. Passeios na ilha - divagações sobre a vida literária e outras matérias. São Paulo: Cosac Naify, 2011, p. 16. 